\title{
EXPLORING SUSTAINABLE NETCHAINS OF SMALLHOLDER COCOA FARMERS IN INDONESIA
}

\section{Wahyudi Wibowo ${ }^{1}$, Lydia Ari Widyarini², Dominicus Wahyu Pradana ${ }^{3}$}

\begin{abstract}
This study aims to investigate the interplay between regional netchain and value chain performance of Indonesia's smallholder cocoa farmers. The investigation was based on in-depth interviews with 45 key informants from two major regional cocoa netchains in the economy. During the interviews, participatory rural assessment technique was employed in order to find out how regional netchain dimensions are interacted with value chain performance. The findings proved the roles of governance mechanism and social embedding into the value chain performance. Governance mechanism was regarded as the most important variable to secure price stability, hence leads to a viable and sustainable regional netchain of cocoa production. Furthermore, social embedding also played an important role through the influence of patron-client systems.
\end{abstract}

Key words: regional netchain, value chain, smallholder farmers, governance mechanism, social embedding, cocoa farmers.

JEL ${ }^{4}:$ M29, O13, Q12, Q13

\section{Introduction}

Cocoa beans, main ingredient for chocolate making, are produced in tropical regions around the equator, where climate conditions are suitable for cocoa plantation. Around three-fourths of the world's cocoa beans production comes from West African countries, including Ivory Coast, Ghana, Nigeria and Cameroon. The

1 Wahyudi Wibowo, Ph.D., Assistant Professor, Faculty of Business, Widya Mandala Surabaya Catholic University, Jalan Dinoyo no. 42-44, 60265 Surabaya, Indonesia, Phone: +623-1-567- 8478, E-mail: wahyudi@ukwms.ac.id

2 Lydia Ari Widyarini, Ph.D., Associate Professor, Faculty of Business, Widya Mandala Surabaya Catholic University, Jalan Dinoyo no. 42-44, 60265 Surabaya, Indonesia, Phone: +623-1-567-8478, E-mail: lydiaari@ukwms.ac.id

3 Dominicus Wahyu Pradana, MBA, Lecturer, Faculty of Business, Widya Mandala Surabaya Catholic University, Jalan Dinoyo no. 42-44, 60265 Surabaya, Indonesia, Phone: +623-1-567-8478, E-mail: wahyupradana@ukwms.ac.id

4 Article info: Original Article, Received: $13^{\text {th }}$ July, Accepted: $12^{\text {th }}$ October 2021. 
Ivory Coast and Ghana are definitely the two largest producers of cocoa beans, which accounting for around $65 \%$ of the world's cocoa beans production. Table 1. shows world's cocoa beans production in the past three years.

Table 1. World's cocoa beans production (period 2016-2019, in 000 tons)

\begin{tabular}{|l|r|r|r|r|r|r|}
\hline \multirow{2}{*}{ Territory } & \multicolumn{2}{|c|}{$\mathbf{2 0 1 6 / 1 7}$} & \multicolumn{2}{c|}{$\begin{array}{c}\text { Estimates } \\
\mathbf{2 0 1 7} / \mathbf{1 8}\end{array}$} & \multicolumn{2}{c|}{$\begin{array}{c}\text { Forecasts } \\
\mathbf{2 0 1 8} / \mathbf{1 9}\end{array}$} \\
\hline Africa & 3,617 & $76.4 \%$ & 3,496 & $75.2 \%$ & 3,701 & $76.3 \%$ \\
\hline Cameroon & 246 & & 250 & & 270 & \\
\hline Cote d'Ivoire & 2,020 & & 1,964 & & 2,220 & \\
\hline Ghana & 969 & & 905 & & 830 & \\
\hline Nigeria & 245 & & 250 & & 250 & \\
\hline Others & 137 & & 127 & & 131 & \\
\hline America & 758 & $16.0 \%$ & 836 & $18.0 \%$ & 842 & $17.4 \%$ \\
\hline Brazil & 174 & & 204 & & 200 & \\
\hline Ecuador & 290 & & 287 & & 310 & \\
\hline Others & 294 & & 345 & & 332 & \\
\hline Asia and Oceania & 357 & $7.5 \%$ & 319 & $6.9 \%$ & 306 & $6.3 \%$ \\
\hline Indonesia & 270 & & 240 & & 220 & \\
\hline Papua New Guinea & 38 & & 36 & & 40 & \\
\hline Others & 49 & & 43 & & 46 & \\
\hline World total & 4,731 & $100.0 \%$ & 4,651 & $100.0 \%$ & 4,849 & $100.0 \%$ \\
\hline
\end{tabular}

Source: ICCO, 2019.

There has been concern on the sustainability of cocoa production over the past decade. World chocolate producers have been under pressure to get sustainable supplies. They seek for more information about their supply chain credibility and even a full traceability of each cocoa bean used in their products (Kuit, Waarts, 2014). Table 2. provides data of world's cocoa beans production, grindings and stocks in past ten years. Gross crops have been quite dynamic for the period of 2009-2016, and then followed with weakening movements for two years.

A major background to the said concern is the facts that cocoa farmers in the main producing countries only receive an average of $6.6 \%$ of the total added value in the world cocoa-chocolate industry, compared to the intermediate product processing industry and final producers who respectively enjoy 7.6\% and 35.2\% (Anga, 2015). The low gain encourages young farmers to leave cocoa plantations and look for more rewarding jobs. The situation gets severe due to the falls of cocoa beans prices, which has taken place since year 2016 (Figure 1.). 
Table 2. World's cocoa beans production, grindings and stocks (period 2009-2019)

\begin{tabular}{|l|r|r|r|r|r|r|r|}
\hline \multicolumn{7}{|c|}{ World cocoa beans production, grindings and stocks } \\
\hline $\begin{array}{l}\text { Crop Year } \\
\text { (Oct-Sep) }\end{array}$ & \multicolumn{2}{|c|}{ Gross crop } & \multicolumn{2}{|c|}{ Grindings } & $\begin{array}{c}\text { Surplus/ } \\
\text { deficit }\end{array}$ & $\begin{array}{c}\text { Total end- } \\
\text { of-season } \\
\text { stocks }\end{array}$ & $\begin{array}{c}\text { Stocks to } \\
\text { grindings } \\
\text { ratio }\end{array}$ \\
\hline \multicolumn{7}{|c|}{} \\
\hline
\end{tabular}

Source: ICCO, 2019.

Figure 1. Trend of cocoa bean prices (period November 2014 - May 2019)

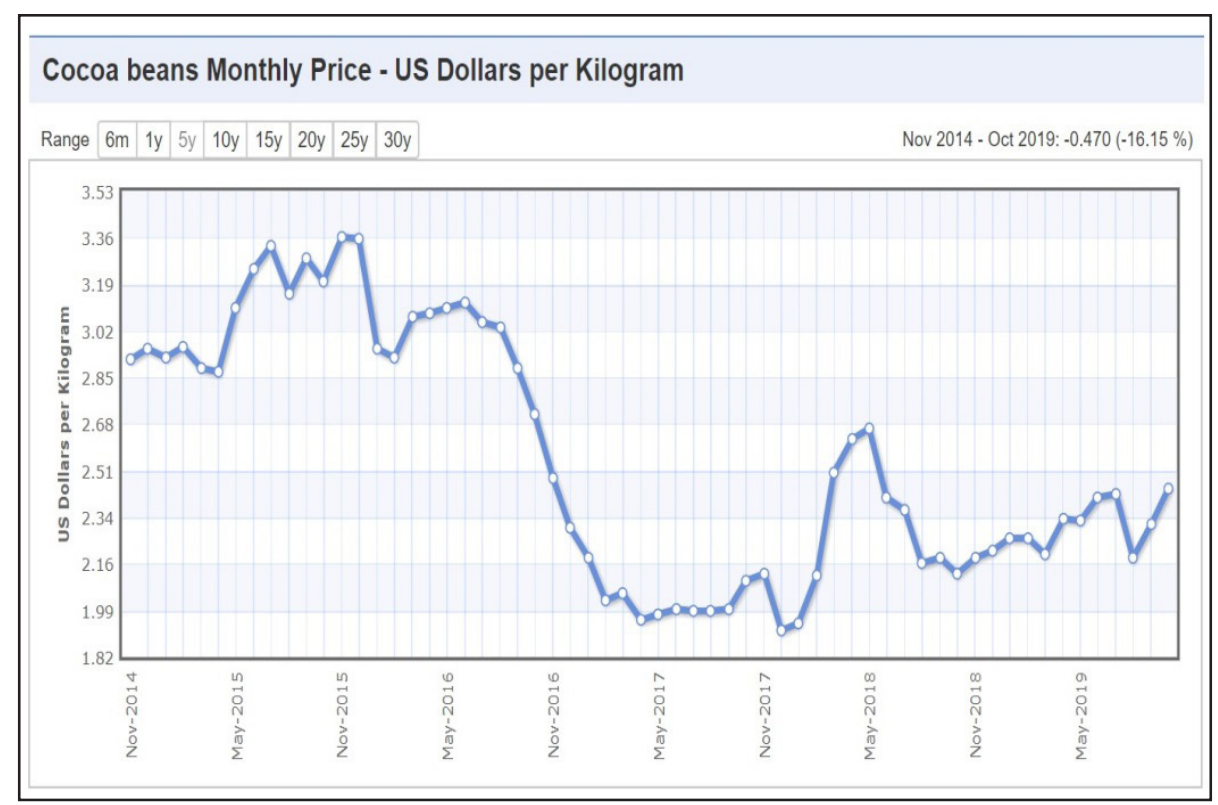

Source: ICCO, 2019. Cocoa daily prices, average of ICE Futures Europe London and US NY. 
In line with the development of this problem, main players in the world cocoachocolate industry have formulated some initiatives on long-term sustainable production (VECO, 2011). As applied to coffee beans production, the initiatives are related to fair trade practices. The adoption of international Fairtrade certification is a new trend among cocoa producers. At the international level there have been around $22 \%$ producers with Fairtrade certification (Potts et al., 2014).

Indonesia is among the main cocoa producers in the world, which alone represents $5.7 \%$ share of the total world cocoa production in 2016/17 (ICCO, 2019). Cocoa growing in Indonesia was first introduced by the Spaniards in the year 1560 . Since then, cocoa had been a commodity for export. However, the export values were continued to decrease in the early of 1900 s due to pest attacks on cocoa plants. About the same period, in 1888 Dutch planters brought in new seedling from Venezuela to Central Java, and it was the commencement of cocoa processing in East Java and Sumatra.

Nowadays cocoa cultivation in the archipelagic country is carried out in more than 1.5 million ha and produces annual exports worth 1.2 billion USD. Behind these figures, smallholder farmers produce the vast majority of cocoa beans (93\%). It is estimated that more than one million smallholder farmers are engaged in cocoa cultivation, with each possesses less than 0.5 ha of land (VECO, 2011).

Amid some established improvements in Indonesia's cocoa production there has been an appealing concern about its low productivity. Overall cocoa production in this country has continued to decline since year 2014. The total of Indonesia's cocoa beans production reached 410,000 MT in the period of 2012/2013, but has been declined to only 260,000 MT in 2017/18 (ICCO, 2019).

The above concern may be related to the facts that the majority of smallholder cocoa farmers are unorganized, untrained, and with low income (Cocoa Sustainability Partnership, 2013). This is happened when farmers receive only a small portion from the total added value generated in the value chain. This unfavorable condition later discourages future cocoa cultivations and potentially threatening the sustainability of cocoa production in the country. In this regards, smallholder farmers' limited access to quality price signals may also contribute to the situation. It reflects a deep fragmentation in Indonesia's cocoa value chain, where smallholder products are sold via a long, poorly regulated, yet highly competitive value chains (Figure 2.).

In relation to the above, several empirical studies highlighted the poor performance of the cocoa value chain in Indonesia. The poor performance of the cocoa value chain was indicated by the low yields and the low quality of cocoa beans. In addition, the marketing chain was also less effective (VECO, 2011; Syahruddin, 
2013). In East Java Province, cocoa farmers tend not to implement the Good Handling Practices due to the small income margin offered in the value chain (Raharto, 2016)among others through the Gross Domestic Product (GDP. Furthermore, with regards to fair trade practices, there was only $10 \%$ of certified Indonesian cocoa producers in year 2013 (Potts et al., 2014). These backgrounds are certainly major impediments to the sustainability of the cocoa beans production in Indonesia. Therefore, more in-depth knowledge is needed on the value chain performance among the smallholder cocoa farmers.

Figure 2. Cocoa value chain in Indonesia

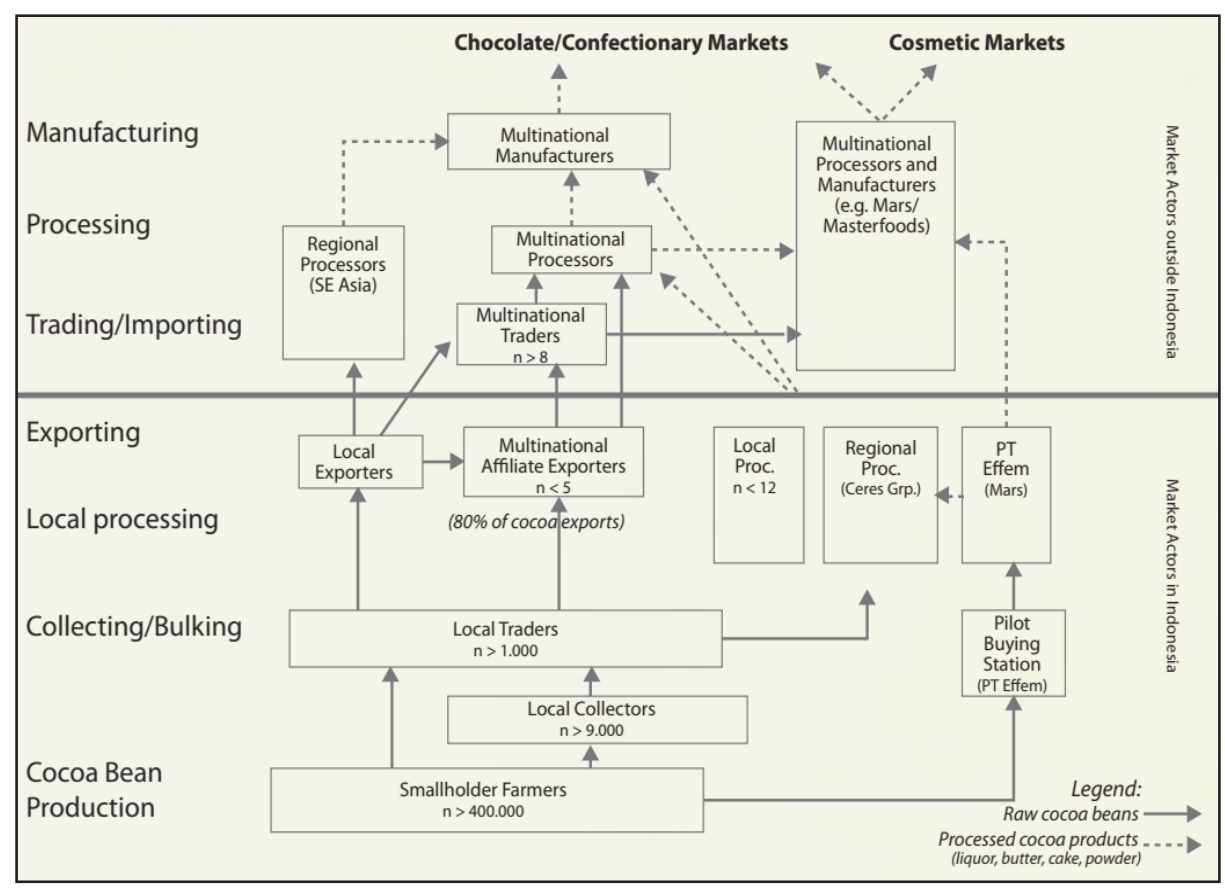

Source: VECO, 2011.

One of the main sources of Indonesian cocoa beans production is the East Java Province. The cocoa (Theobroma cacao) commodity is one of the leading commodities in the plantation sub-sector in East Java. The East Java cocoa commodity contributes to meet the needs of both domestic and export markets. Though production volume of cocoa beans in East Java is relatively small compared to major cocoa producing areas such as Sulawesi, the cocoa production and distribution systems in East Java is advanced.

In East Java the cocoa commodity is planted both by the People's Plantation (Perkebunan Rakyat), the State Large Plantation (PT. Perkebunan Nusantara), and 
the Large Private Plantation (Perkebunan Besar Swasta). People's Plantation is the biggest contributor to cocoa supply, which is $57 \%$, from the total East Java cocoa production $(26,000$ tons in year 2012).

The East Java Provincial Plantation Office recorded that in 2012 the cocoa plantation area in East Java consisted of 32,010 ha of people's plantations, 26,487 ha of stateowned plantations, and 4,543 ha of private owned plantations. The centers for people's plantation in East Java Province include Blitar, Malang, Trenggalek, and, as well as 18 other regencies.

The government of East Java Province by far has paid attention to the cocoa production in the province, especially those which come from the smallholder farmers. Efforts to develop cocoa new plantation centers in East Java currently lead to the southern region of East Java. This southern region area is considered to have an agro-ecosystem typology that is suitable for cocoa cultivation. Since year 2015, the government has initiated the Cocoa Belt (Sabuk Kakao) program, which stretched across eight districts $(634.11 \mathrm{~km})$. Under the program government provides supports to smallholder cocoa farmers in kind of cocoa seeds and technical assistances.

According to the study of the Research Board of East Java Province (RBEJP, 2015) there are various key constraints to value chain performance of smallholder cocoa farmers in East Java Province. The constraints include (1) weak institutional capacity of farmers and the agribusiness actors in the region, (2) limited capital control, business management, and technology, (3) low access to existing business opportunities, and (4) the sustainability threat of production. Therefore, strengthening the institutional aspects and the market power of smallholder farmers are both essential.

In general, this study aims to obtain the general perception of smallholder cocoa farmers on the issue of value chain performance. In particular, this research is intended to give response to the question: "How governance mechanism and social embedding among smallholder cocoa farmers affect the value chain performance of cocoa beans production in East Java?" To answer this question, the present study aimed at constructing a framework that relates value chain analysis (Antonio, Griffith, 2017) and the netchain model (Nijhoff Savvaki et al., 2012). The basic assumption being to secure the farm's continuity, the generated value chains among the value chain actors should be supported by a viable and sustainable regional netchain model.

This paper will proceed as follows. The next section will explain the theoretical foundation of the study. This covers literature reviews on the possible interplaybetween the regional netchain model and value chain performance. Section 3. explains the research methodology and approaches, which are applied to two important regional cocoa netchains in East Java Province, Indonesia. Section 4. provides discussion 
on the mapping of cocoa netchains in the province and their respective value chain performances. Finally, conclusion and policy implications are provided in Section 5.

\section{Literature Review}

A conceptual framework for the present study is adopted from past studies in the field with a focus of discussion to propose possible associations between netchain model and value chain performance. The framework is primarily based on the netchain model (Lazzarini et al., 2001; Nijhoff Savvaki et al., 2012) and the social network model (Uzzi, 1997). Another underlying concept applied in this study is value chain analysis (Antonio, Griffith, 2017; Rota, Sperandini, 2010).

Netchain is a set of networks encompassing horizontal ties of firms within a particular industry or group, such that these networks (or layers) are sequentially organized based on the vertical ties of firms in different layers (Lazzarini et al., 2001; Nijhoff Savvaki et al., 2012). The netchain model provides value chain and network perspectives on inter-organizational partnership.

The netchain model is built around two important dimensions, governance mechanism and social embedding. Following the previous studies, this present study views governance mechanism of a netchain as means of creating the conditions for effective partnership in the netchain (Jones et al., 1997; Nijhoff Savvaki et al., 2012) local and/or regional. Such conditions that concern with partner selection, type of agreements, as well as strategic coordination within the netchain. Thereby three elements of governance mechanism: chain coordination, chain quality management systems and chain information systems, are recognized.

This study also regards the dimension of societal embedding (Nijhoff Savvaki et al., 2012). Societal embedding is the extent to which social values that represent the cocoa beans production and its chain are shared by its wider network of stakeholders, consumers and society in general.

A value chain is a concept which represents a set of activities for a firm to perform so as to provide a valuable product or service (Porter, 1985). Value chain is based on the process view of a firm where each subsystem within the firm creates specific value to the made up of the final marketable product or service. In the value chain, each activity involved must be separated to each other, since it has different economic value and represent a significant proportion of cost. Hence how value chain activities are carried out determines costs and latter affects profits. 
In this study, the value chain analysis refers to the analysis of a value system or an industry value chain. A value system comprises of suppliers of inputs, a production firm of a marketable product, the distributors who pass the product all the way to the end customers. To achieve a sustainable production of a marketable product, a firm must understand the work of the value system which gives respect to the contribution of every stakeholder in the system.

In agribusiness, value chain system can be defined as a set of necessary activities to bring an agricultural product from plantation to end consumers, where at each stage value is added to the product. This involves the identification of power relationship among the stakeholders and some aspects of organization and the coordination within the system (Antonio, Griffith, 2017). In global chocolate industry, for instance, the value chain system links local farmers to collectors and brokers of cocoa beans, also to the multinational buyers and processors at the end of the chain.

\section{Methodology}

To achieve its purposes the present study was designed as field studies which use qualitative-descriptive approach. Referring to a previous study, conducted by Raharto (2016)among others through the Gross Domestic Product (GDP, the field study was conducted in Blitar Regency. In addition, another field study also took place in Mojokerto Regency.

The choice on these two regencies was based on their active participation in the Sustainable Cocoa Development Program (SCDP) in East Java Province. The program was a collaborative project of the Association of Export Companies in Indonesia (Gabungan Perusahaan Ekspor Indonesia, GPEI), Pusat Penelitian Kopi dan Kakao (PUSLITKOKA), East Java Provincial Government, and the European Union. The program aimed to encourage the sustainability of the cocoa supply chain in East Java.

Blitar Regency is one of the main centers for cocoa production and distribution in East Java Province. The regency is home for thousands of smallholder cocoa farmers who belong to the Guyub Santoso Farmer Cooperative (hereinafter Guyub Santoso). Guyub Santoso was established on $1^{\text {st }}$ January 2005. The establishment of the farmer cooperative was intended as an effort to joint production and distribution. Through the cooperative mechanisms, cocoa bean products are collected, to be further processed and distributed. However, in year 2017, there was a shift on the governance of the netchain that is from a cooperative to a corporation. This shift will later played several implications to the value chain network. 
The membership of Guyub Santoso includes 26 farmer groups in Blitar Regency and 78 other farmer groups in East Java. There are around 4,240 smallholder farmers in Blitar Regency and 17,774 smallholder farmers from other regencies. Its productivity is supported by about 17,415 ha of productive lands.

In Mojokerto Regency, the field study was conducted in Mulyo Jati Farmer Cooperative (hereinafter Mulyo Jati). The farmer cooperative has just established in year 2016, and was started with only 20 groups of cocoa farmers. Before its establishment, Mulyo smallholder cocoa farmers in Mulyo Jati had been part of the value chain network of Guyub Santoso. Few years after its establishment, the cooperative has been able to gather a number of 1,337 smallholder cocoa farmers. The land areas involved in the cocoa production for this center cover 447 ha. This center of cocoa plantation, with regards to production scale and land occupation, is relatively small compare to the one in Blitar Regency. But, the growth and members' participation of the value chain network are subjects of interesting study.

The field studies in two regencies were consisted of observation, in-depth interview, and participatory activities. The studies were conducted in six months (January to June 2019). The focus of the research was to identify the roles of institutional aspects, governance, and social networks among the cocoa value chain actors. The data collection method used was Participatory Rural Appraisal (PRA) through semi-structured socio-economic interviews to smallholder cocoa farmers in the two regencies.

The PRA method allows value chain actors to jointly evaluate their existing problems in order to formulate joint efforts and policies related to the sustainability of cocoa value chain. In its implementation, PRA emphasizes direct involvement of the smallholder farmers.

The analysis was conducted in descriptive techniques by employing combine tools of value chain analysis and Delphi analysis. A number of key informants from Blitar Regency $(n=15)$ and from Mojokerto Regency $(n=30)$ were involved during the study. The informants were all chairmen of local cocoa farmer groups, which were selected through purposive sampling technique.

During the study, we asked the informants factors contributed to their choice to grow cocoa plant out of other commodities. Then we asked them to identify the factors according to the priority. Often, we confronted their answers to other possible factors. We also asked them how they joined and engaged in the existing value chain network. Again, we confronted them with other possible choices. 
Next, we facilitated the informants to explain in detail how the value chain network works in growing cocoa plant, collecting cocoa beans, setting the quality standard and grading, determining the cocoa bean prices, and processing and selling of the cocoa beans. We facilitated them as well to describe their problems in dealing with the production and distribution of the cocoa beans. Informants were then asked about their ideas to solve the actual problems. In the last part, we asked them to express their expectations regarding the future of the value chain network.

\section{Results and Discussion}

First important aspect to discuss in this part is the socio-economic backgrounds of the smallholder farmers in Blitar and Mojokerto regencies. The smallholder farmers in both regional netchains are from various occupational backgrounds. When informants were asked to identify their occupation, there were various answers including small business owner or merchant, government officer, craftsman, school teacher, or cleric.

Cocoa growing is not the only source of income for the smallholder farmers. They came into the cocoa growing generally by the intention to make use of their unproductive lands. However with regard to their total income, the cocoa farmers are also at various economic conditions. There are only few farmers with the above standard income - that is in reference to the minimum wage in the region, but the majority of the farmers still live with below standard of income.

When informants were asked about their choice to grow cocoa plant, the answers were similar. Cocoa growing is favorable due to low costs and eases of treatment and maintenance. Unlike other kinds of plantation such coffee, coconut, and tea, treatment on cocoa plantation is relatively effortless. Moreover, it requires no specific skills. This is a job with no entry barriers. Every household with some piece of land can access the value chain system as growers. Cocoa farming in East Java is gender inclusive, men and women are involved equally.

Next important aspect is how in fact the regional netchains of smallholder cocoa farmers, Guyub Santoso and Mulyo Jati, work. It is important to identify that smallholder farmers regards price stability over high price. Furthermore, compare to other factors, price stability is actually the most important factor toward the continuation of cocoa growing. The reason behind this opinion lies on the farmers' past experiences. 
Like most food producing chains, cocoa farmers in the two netchains faced market risks related to the dynamic of world prices. However, for smallholder holders with relatively small volume of production, it is unfavorable to accept the ups and downs of world cocoa bean prices. Even at the time of high prices, income from cocoa beans selling does not cover their daily needs.

Therefore, in the view of these smallholder farmers viable and sustainable netchain simply means value chain network that could secure stable cocoa beans prices. Keep in mind that the idea of viable here is dissimilar to the idea that underlies the concept of fair price. In the fair price principle, there is a concern to ensure a minimum price that covers the production costs of farmers. Also, fair price is supposed to achieve a fair distribution of benefits within the value chains. However, the idea of having a viable netchain here refers to the condition where the stability over the highest possible price of cocoa beans is achieved in the market.

Following this principle, there is less care among the smallholder farmers towards the quality of cocoa beans. This is happened since collectors usually do not require high quality of cocoa beans. This of course represents the farmers' lack of knowledge and concern towards the dynamics of cocoa prices in the world market, which is the main concern of cocoa traders. Obviously, there is a gap between the perspectives of smallholder farmers and collectors. Moreover, there is no strict regulation - as it is for the coffee beans product - that prohibits farmers from directly selling raw cocoa beans product to collectors.

Turning into the dimensions of governance mechanism in the netchain and how it works, there are several important findings. Chain coordination among smallholder farmers in East Java is unique with regards to its structure. Smallholder farmers in both netchains of Guyub Santoso and Mulyo Jati are actually less organized. Even when all of them are belong to farmer cooperatives, but these farmer cooperatives do not work as it should. In fact, both of the cooperatives are more likely perform as farmer associations. Farmer cooperatives in the two netchains act only as forum to exchange information on the production volume and the price, also to facilitate transactions.

Reflecting on how the chain coordination works in two netchains, it is based on principle of information transparency. Transparency of information is highly important since it is the basis for trust among actors in the netchain. In Blitar Regency, Guyub Santoso functions as netchain manager and is responsible for the overall value chain performance. The cooperative price system, which referring to the world market prices, offers farmers with more certainty, thereby opposing opportunistic behavior and creates security in production volumes. 
Similar price system is employed in Mojokerto, but with an additional assurance of minimum price level. Hence Mulyo Jati offers the smallholder farmers a more competitive price system which allows farmers to get higher bottom price. Obviously in this price system there is transfer of price fluctuation risk from farmers to Mulyo Jati. This system is near to the work of fair price system.

Chain-wide information exchange is crucial in the work of the cocoa farmer netchains. Chain-wide information exchange and its practice play a central role in all stages of the production and distribution processes. It could determine the quality of the end product, and importantly contribute to the effectiveness of the value chain performance.

Out of the common ways of managing the chain coordination in the two netchains of cocoa farmers in East Java, there is a different mechanism of managing the exchange of information. The exchange of information in Guyub Santoso is more likely following a business mechanism, especially it is transformed into a corporation. While in the case of Mulyo Jati, the way it is conducted is rather through social networks. Exchange of information often takes place through a weekly-routine praying assembly.

Concerning the chain-wide information exchange in the two cases of cocoa netchain, their successfulness depends on the quality of relationships among the individual actors. Good relationship will enable a constant exchange of information within the various stages of the netchain. By this person to person communication, information collected, processed, and disseminated during the production and distribution processes.

Important production information includes identification of harvesting schedules as well as the quality of the cocoa bean product. A large part of this information exchange is conducted through social media network. However, this way of information exchange is seldom documented.

Overall, on governance mechanism the existence of a chain manager (i.e. farmer cooperative) seems crucial to the success of netchain model. For regional cocoa netchains to enjoy market growth, a structured form of partnership among chain actors is a precondition.

Next, on being socially embedded (e.g. in terms of shared culture and tradition or societal concerns) being region-bound is critical for an effective netchain model. Collaborative action and effective communication among actors in the value chain are all important. In this sense, this study finds interesting evidence. Almost all of the smallholder farmers are members of or at least associate 
themselves with the same religious community, named Nahdlatul Ulama. In Indonesia, Nahdlatul Ulama is the biggest Moslem community.

Hence, social networks play important role as the basis for relationship and trust among actors in the netchain model. These various actors involved in patronclient relationships, which ultimately represents a system of informal governance in the netchains. That is to say, much of the actual social and economic activities that take place in the netchain was guided by the patron-client structure. This is applied for both Guyub Santoso and Mulyo Jati, however the latter has been more effective in taking advantage from the social networks.

The results imply that government supports are needed to promote the functioning of farmers' cooperation, especially in the center areas of cocoa bean and other agricultures production. Government interventions, in this regard, need to take into account the contribution of the established social-institutional setting in the local communities, which could bring effective supports to work of a viable and sustainable netchain.

\section{Conclusion}

The present paper started with assumption on the existence of business case from a regional netchain of agricultural production that involves smallholder farmers. The research approaches then allow a comparative study of two cases of cocoa production in East Java. This study finds that the most important factor for cocoa growing is price stability. Second most important is governance mechanisms, especially on the aspect of chain-wide information exchange.

There are four important issues to take into consideration for regional cocoa netchains in East Java when they aim to manage their future development. The first is pertained to chain coordination, especially in choosing the most appropriate organizational structure for the regional netchain (e.g. control board/council, cooperative, or corporation). The second important issue is to guarantee the effectiveness of chain-wide information exchange. The third important issue is that of social embedding. It is important for the netchain model to perform well through societal embedding mechanisms, such as in terms of mobilizing and involving societal organizations in the process of building up the production system.

Knowing those important factors for the sustainability of cocoa growing, any firms engage to form business case with the smallholder farmers need to establish a governance mechanism that ensure the present of price stability. Next, the 
involvement of firms, which are presumably external to the community of farmers, should take care of the traditional social ties in the community.

The regional cocoa netchains in East Java, as performed by Guyub Santoso and Mulyo Jati are still at early stage of development. Yet, if the regional production and distribution networks continue to be developed at the same rate as they did in the past few years then these regional cocoa netchains seem having some potential for future growth.

Furthermore, recognizing that governments in most developing economies typically do not have sufficient financial budget to invest in value chain development programs, it may be critical to encourage smallholder farmers' cooperation through netchain and social embedding. The netchain can work together in risk-sharing, improving insurance through sustained supply of input, standardized production processes, quality control, and join distribution. These efforts will help to alleviate smallholder farmers' constraints and the cocoa value chain performance can be upgraded. In contrary, fragmented smallholders and failure to make coordination will result in an inefficient value chain.

It is suggested for future researches to define the roles that local government and communities can do, in close partnership with the netchain actors (Maryam et al., 2021; Manikas et al., 2019). That is, for instances, supporting product and geographical indication certifications, strengthening organizational structures and coordination, or developing branding strategies. Therefore, government and non-government institutions have to work together to improve the value chain performance. Government institutions should work in ensuring the balance of various barriers, incentives, and stakeholder interests (Maryam et al., 2021; Janvry et al., 2019; UNEP, 2019). Local communities and non-government institutions should measure and compare the degree to which various production systems meet requirements and expectations of the society, and communicate them to the netchain they are affiliated.

In this regard, it is also noteworthy to acknowledge the framework of Sustainable Food Value Chains Knowledge (SFVC), which is introduced by the Food and Agriculture Organization of the United Nations. In the SFVC development, a holistic triple bottom line approach is applied. The approach recognizes three main dimensions of sustainability, specifically economic, social and environmental dimensions (FAO, n.d.).

In the economic dimension, a food value chain is regarded as sustainable when the activities performed by each stakeholder are commercially viable, 
or economically viable for public services budget. In the social dimension, sustainability means socially and culturally acceptable value chain activities in terms of the distribution of costs and benefits which bring increased value creation along the value chains. In the environmental dimension, sustainability refers to the ability of value chain players to bring neutral or positive impacts on the natural environment from their value chain activities.

In the future, in order to reap the benefits from the global increased demand of cocoa beans, investment and efforts in developing viable and sustainable netchain are required. Aligned with this, participation of the private sectors and matching the netchain activities with other input services may be needed.

\section{Literature}

1. Anga, J. (2015). Latest developments in the global cocoa market. United Nations Conference on Trade and Development (UNCTAD), Geneva, Switzerland.

2. Antonio, L., Griffith, G. (2017). The cashew value chain in Mozambique: analysis of performance and suggestions for improvement. International Journal of Food System Dynamics, 8(83):208-221.

3. Cocoa Sustainability Partnership (2013). The 2020 Roadmap to Sustainable Indonesian Cocoa. NewForesight Consultancy, Utrecht, the Netherlands.

4. FAO (n.d.). Sustainable Food Value Chains Knowledge Platform. Food and Agriculture Organization (FAO), Rome, Italy, retrieved at: www.fao.org/ sustainable-food-value-chains/home/en/, $8^{\text {th }}$ October 2021.

5. ICCO (2019). Production of cocoa beans. ICCO Quarterly Bulletin of Cocoa Statistics, XLIV(3/Cocoa year 2018/19), published 30 ${ }^{\text {th }}$ August 2019, retrived at: www.icco.org/icco-documentation/quarterly-bulletin-of-cocoastatistics/, $5^{\text {th }}$ June 2021.

6. Janvry, A., Sadoulet, E., Trachtman, C. (2019). Achieving Coordination in Agricultural Value Chains: The Role of Lead Agents and Multi-stakeholder Platforms. Foundation for Studies and Research on International Development (FERDI), Clermont Ferrand Cedex, France, Working Paper no. 254, pp. 1-29.

7. Jones, C., Hesterly, W., Borgatti, S. (1997). A general theory of network governance: Exchange conditions and social mechanisms. Academy of Management Review, 22(4):911-945. 
8. Kuit, M., Waarts, Y. (2014). Small-scale farmers, certification schemes and private standards: Is there a business case? Technical Centre for Agricultural and Rural Cooperation ACP-EU (CTA), Wageningen, the Netherlands.

9. Lazzarini, S., Chaddad, F., Cook, M. (2001). Integrating supply chain and network analyses: The study of netchains. International Journal on Food System Dynamics, 1(1):7-22.

10. Manikas, I., Malindretos, G., Moschuris, S. (2019). A Community-Based Agro-Food Hub Model for Sustainable Farming. Sustainability, 11(4)1-17.

11. Maryam, N., Nurasa, H., Alexandri, M., Sugandi, Y. (2021). Designing a food supply chain network under public-private community partnership on traditional Indonesia markets. Uncertain Supply Chain Management, 9(4):841-850.

12. Nijhoff Savvaki, R., Trienekens, J., and Omta, S. (2012). Building viable and sustainable regional netchains: case studies of regional pork netchains in Spain, Germany, and the Netherlands. International Journal on Food System Dynamics, 3(1):50-60.

13. Porter, M. (1985). Competitive advantage: Creating and Sustaining Superior Performance. The Free Press, NY, USA.

14. Potts, J., Lynch, M., Wilkings, A., Huppe, G., Cunningham, M., Voora, V. (2014). The State of Sustainability Initiatives Review 2014: Standards and the green economy. International Institute for Sustainable Development, Manitoba, Canada.

15. RBEJP (2015). Survey Pengembangan Potensi UMKM Sektor Agrobisnis di Jawa Timur: Studi Kasus Kampung Coklat, Kabupaten Blitar. Research Board of East Java Province (RBEJP), Dewan Riset Daerah Provinsi Jawa Timur, Indonesia (in Indonesian language, unpublished document).

16. Raharto, S. (2016). Institutional Development Model Cocoa Farmers in East Java Province District Blitar. Agriculture and Agricultural Science Procedia, 9:95-102.

17. Rota, A., Sperandini, S. (2010). Value chains, linking producers to the markets. Livestock Thematic Paper, International Fund for Agricultural Development (IFAD), Rome, Italy, pp. 1-5.

18. Syahruddin, N. (2013). Sustainable Supply Chain Management: A Case Study of Indonesia's Cocoa Industry. Bulletin of Indonesian Economic Studies, 49(1):114-115. 
19. Uzzi, B. (1997). Social structure and competition in interfirm networks: The paradox of embeddedness. Administrative Science Quaterly, 42(1):35-67.

20. UNEP (2019). Collaborative Framework for Food Systems Transformation, A multi-stakeholder pathway for sustainable food systems. United Nations Environment Programme (UNEP), Geneva, Switzerland.

21. VECO (2011). Increased incomes for Indonesian cocoa farmers in sustainable markets: NGO private sector cooperation on Sulawesi island. Vredeseilanden Country Offices (VECO), Leuven, Belgium, retrived at: https://assets.rikolto.org/paragraph/attachments/indonesia-cocoa-case_0. pdf, $4^{\text {th }}$ October 2021. 